\title{
WPLYW STARZENIA SIĘ SPOŁECZEŃSTWA NA POSTĘP TECHNICZNY
}

\section{WSTĘP}

Celem artykułu jest zbadanie wpływu starzenia się społeczeństwa na postęp techniczny oraz oszacowanie jego potencjalnych konsekwencji. Waga tematu wynika $\mathrm{z}$ faktu, że dwa główne motory stopy wzrostu $\mathrm{PKB}^{1}$ - tempo wzrostu siły roboczej i tempo postępu technicznego - notują w krajach rozwiniętych ponadprzeciętnie niskie wartości. Ponadto nie wydaje się prawdopodobne odwrócenie spadkowego trendu, w szczególności jeśli chodzi o pierwszy komponent - na podstawie danych o wzroście demograficznym i umieralności można niemalże $\mathrm{z}$ pewnością wnioskować o kształtowaniu się przyszłej podaży pracy na niespotykanie dotąd niskich poziomach ${ }^{2}$. Problematyka tzw. senioralnej (srebrnej) gospodarki jest już ugruntowana w literaturze i traktowana jako fakt dokonany, niemożliwy do odwrócenia, przynajmniej w średnim okresie. Stąd remedium na stagnacyjna gospodarkę upatruje się w tempie postępu technicznego - jako jedyny jest w stanie zniwelować negatywne efekty starzejącego się społeczeństwa dla stopy wzrostu PKB (a co za tym idzie, dla poziomu życia). Jednak prognozy dotyczące kształtowania się $\mathrm{TFP}^{3}$ nie są jednoznaczne: niektórzy ekonomiści uważaja, że największe rewolucje technologiczne należą już do historii, inni - wprost przeciwnie.

Niezależnie od przewidywań, istotne wydaje się pytanie o ewentualny związek między dwiema omawianymi zmiennymi. Negatywny wpływ starzenia się społeczeństwa na postęp techniczny stawiałby pod znakiem zapytania dalszy wzrost PKB w ogóle. Zbadanie i poznanie zagadnienia pozwoli na stosowne przeformułowanie polityki i sposobu postrzegania wzrostu, co może dać szansę na zamortyzowanie efektu w odpowiednim czasie. Za postawieniem tezy o wpływie starzejącego się społeczeństwa na postęp techniczny przemawia m.in. analiza szeregów czasowych dotyczących kształtowania się agregatów makroekonomicznych w cyklach koniunkturalnych (skorzystano tu z baz

\footnotetext{
${ }^{1}$ M. Burda, Ch. Wyplosz, Makroekonomia. Podręcznik europejski, tłum. B. Czarny, Warszawa 2013, s. 128-130; D. Romer, Makroekonomia dla zaawansowanych, tłum. A. Malawski, Warszawa 2000, s. 44-45.

2 OECD.Stat, Historical Population Data and Projections (1950-2050), <https://stats.oecd. org/Index.aspx?DataSetCode=POP_PROJ> [dostęp: 4.06.2018].

${ }^{3}$ Total factor productivity - miara tempa postępu technicznego.
} 
danych A. Maddisona i T. Piketty'ego) oraz badania empiryczne, w szczególności S. Aiyara oraz G. Adlera.

Artykuł składa się z dwóch części. Pierwsza z nich jest poświęcona zarysowaniu zagadnienia oraz powyżej przytoczonym argumentom przemawiającym za przedmiotowa teza, natomiast druga - ujęciu problemu w model teoretyczny (zmodyfikowany model nakładających się pokoleń) za pomoca oprogramowania Dynare/Octave. Pokazano, że zmiana struktury demograficznej miałaby dużo bardziej dotkliwe skutki dla wyników ekonomicznych, gdyby wspomniane główne komponenty były ze sobą powiązane niż w przeciwnym wypadku.

\section{PODSTAWY TEORETYCZNE I PRAWIDLOWOŚCI EMPIRYCZNE}

\section{Zarys problemu}

Nikłe perspektywy przyszłego wzrostu gospodarczego determinowane sa rekordowo niskim tempem wzrostu siły roboczej oraz postępu technicznego. Pierwsze $\mathrm{z}$ tych zjawisk jest spowodowane względami zarówno ekonomicznymi, jak i społecznymi. Zgodnie z teoria Beckera wraz ze wzrostem zamożności ludności następuje zmniejszenie liczby potomstwa, co umożliwia zainwestowanie większej kwoty w jego ,jakość”. Nie bez znaczenia pozostaja też zmiana modelu stylu życia i rodziny, późniejszy wiek usamodzielniania się, a także powszechnie dostępna antykoncepcja i większa świadomość w tej dziedzinie. Czynniki odpowiadające za spowolnienie postępu technicznego nie sa do końca jasne. Powszechnie uważa się, że zahamował on na skutek kryzysu finansowego i od tamtego czasu podlega histerezie, tj. trwałej zmianie spowodowanej efektem cyklicznym. Dane jednak wskazuja, że spowolnienie wystapiło już przed 2008 r., co skłania do tezy o wpływie czynników strukturalnych.

Należy mieć na względzie, że niskie tempo wzrostu siły roboczej w przyszłości to niejako fakt dokonany, tzn. determinowany aktualnym przyrostem demograficznym. Wprawdzie państwo może prowadzić politykę nakierowana na jego zwiększenie, nie tylko jednak ma ona ograniczoną skuteczność, lecz także działa ze znacznym opóźnieniem (czas od narodzin nowego pokolenia do jego wejścia na rynek pracy). W związku z tym jedynym motorem wzrostu stopy PKB, który pozostaje, jest tempo postępu technicznego. Powstaje pytanie, czy warto pokładać w nim nadzieję, gdyż dane z ostatnich lat nie napawają optymizmem. Przeciętny wzrost TFP w krajach rozwiniętych znajduje się poniżej jakiegokolwiek poziomu osiaganego na przestrzeni ostatnich 60 lat, a przez ostatnie 10 wynosił niemal zero. Poniżej zamieszczono szereg czasowy kształtowania się odnośnych wartości od 1880 do 2010 (TFP obliczono jako resztę Solowa). 


\section{Wykres 1}

Tempo wzrostu PKB, postępu technicznego i przyrostu demograficznego w krajach rozwiniętych w latach 1880-2010 (dziesięcioletnie stopy wzrostu)

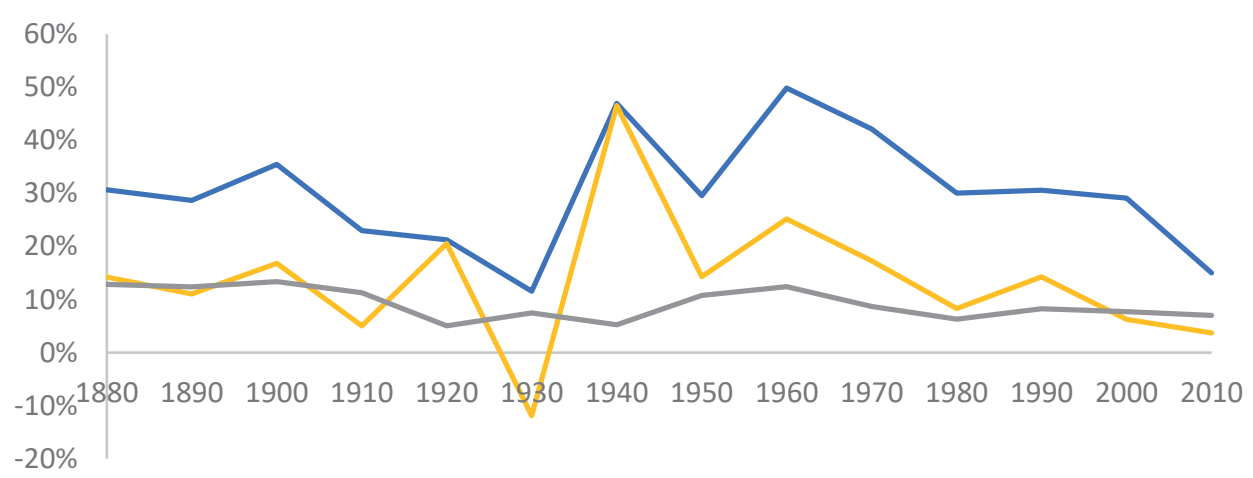

-Stopa wzrostu PKB —Stopa wzrostu TFP —Stopa przyrostu naturalnego

Źródło: opracowanie własne na podstawie Maddison Historical Statistics, <http://www.ggdc.net/maddison/oriindex.htm> [dostęp: 14.02.2018]; Piketty's Capital in the 21st century Database, <http://piketty. pse.ens.fr/en/capital21c2> [dostęp: 14.02.2018].

\section{Prognozy TFP}

Debata dotyczaca kwestii, czy wzrost gospodarczy oparty na innowacjach się już wyczerpał, jest jedna z najbardziej żywych dyskusji w ekonomii ostatnich lat. R. Gordon wskazuje, że na przestrzeni wieków żadne innowacje nie przyczyniły się do wzrostu produktywności aż tak, jak elektryczność oraz silnik parowy ${ }^{4}$ (właczajac w to komputery i Internet). Podobne zdanie prezentuje H. Chang, który powołując się na prawo malejącej produktywności, twierdzi, że początkowe innowacje zawsze będą przynosiły największą korzyść, gdyż poziom, z jakiego dokonuje się startu, jest bardzo niski ${ }^{5}$.

Antagonista R. Gordona - J. Mokyr wskazuje na fakt, że debata na temat wyhamowania możliwości wzrostu w gospodarce toczy się już od początków historii ekonomii ${ }^{6}$. Groźba ich całkowitego wyczerpania, podnoszona najgłośniej przez T. Malthusa ${ }^{7}$, spowodowana była nieprzewidzeniem możliwości

${ }^{4}$ R.J. Gordon, The Rise and Fall of American Growth: The U.S. Standard of Living since the Civil War, New Jersey 2017, s. 25 i n.; TED Talk, Robert Gordon: The Death of Innovation: The End of Growth, <https://www.ted.com/talks/robert_gordon_the_death_of_innovation_the_end_of_ growth> [dostęp: 15.02.2018].

${ }^{5} \mathrm{H}$. Chang, 23 rzeczy, których nie mówiq ci o kapitalizmie, tłum. B. Szelewa, Warszawa 2013, s. 56-68.

${ }^{6}$ J. Mokyr, The Culture of Growth: The Origins of the Modern Economy, New Jersey 2016, s. 339-342; EconTalk Episode with Joel Mokyr, Joel Mokyr on Growth, Innovation and Stagnation, <http://www.econtalk.org/archives/2013/11/joel_mokyr_on_g.html> [dostęp: 15.02.2018].

7 Prace T. Malthusa zaowocowały nadaniem ekonomii przydomka „ponurej nauki”, co zreszta nie wydaje się przesadzone w obliczu faktu, że w modelu malthusiańskim część ludności musiała 
pojawienia się postępu technicznego. W gospodarce malejącej krańcowej produktywności muszą istnieć granice wzrostu, innowacyjność okazała się jednak zdolna do ich przesuwania. J. Mokyr postrzega krytyczne podejście do przyszłego wzrostu innowacyjności jako głos malthusiańskiego pesymizmu, niedoceniający ludzkich możliwości i szans, jakie stawiają przed nami np. badania nad sztuczną inteligencja ${ }^{8}$, natomiast spowalniający TFP - jako nieadekwatną miarę postępu technologicznego, wskaźnik zaprojektowany dla innego rodzaju gospodarek niż współczesna ${ }^{9}$.

Niezależnie od tego, która ze stron dyskusji jest bliżej prawdy, wydaje się, że należy podawać w wątpliwość każde ze skrajnych stanowisk, lecz zarazem być przygotowanym na najgorszy możliwy scenariusz. Pozwoli to przygotować działania mogace złagodzić potencjalne szoki.

\section{Przyczyny spowolnienia tempa wzrostu TFP}

Mimo że przyczyny wyhamowania tempa wzrostu postępu technicznego nie są do końca jasne, wyróżnia się dwie grupy czynników majace wpływ na to zjawisko: cykliczne (związane z kryzysem finansowym 2008 r.) i strukturalne.

Do tej pierwszej kategorii należą zaostrzone warunki kredytowania, które obniżyły inwestycje firm, w tym te na badania i rozwój ${ }^{10}$ (ta grupa wydatków zachowuje się procyklicznie $\left.{ }^{11}\right)$. Niski poziom inwestycji spowodowany jest także wysoką niepewnością polityczno-gospodarcza, co sprawia, że firmy preferują przedsięwzięcia o niskim ryzyku i niższej stopie zwrotu ${ }^{12}$. Spadek inwestycji

umrzeć, żeby starczyło środków utrzymania dla pozostałych. Zob. H. Landreth, D.C. Colander, Historia myśli ekonomicznej, tłum. A. Szeworski, Warszawa 2008.

${ }^{8}$ Gordon zwraca uwagę, że sztuczna inteligencja nie znajdzie masowego zastosowania w codziennym życiu, a najintensywniej wykorzystywana będzie w mało produktywnych branżach gospodarki (np. marketing).

9 Jego krytyka obejmuje m.in. pomijanie przez TFP darmowego dostępu do informacji, który w sposób znaczący przyczynia się nie tylko do wzrostu poziomu życia, lecz także do rozprzestrzeniania się myśli innowacyjnej.

10 Firmy o słabej strukturze aktywów obniżyły inwestycje w wartości niematerialne o od 0,5 do 0,81 punktu procentowego silniej w stosunku do swoich efektywniejszych konkurentów. G. Adler et al., Gone wih the Headwinds: Global Productivity, IMF Staff Discussion Note SDN/17/04, 2017, s. 16.

11 D. Garcia-Macia, The Financing of Ideas and the Great Deviation, IMF Working Paper WP/17/176, 2015, s. 26 i n.; M. Ridder, Investment in Productivity and the Long-Run Effect on Financial Crises on Output; CESifo Working Paper Series No. 6243, 2017, s. 35.

12 Wysokie ryzyko polityczno-gospodarcze odpowiada za spadek TFP o 0,2 punktu procentowego w Europie, 0,1 - w Japonii i 0,07 - w USA; D. Andrews, C. Criscuolo, P. Gal, Frontier Firms, Technology Diffusion and Public Policy: Micro Evidence from OECD Countries, OECD Productivity Working Papers No. 2, 2015, s. 10 i n.; R. Decker et al., Where Has All the Skewness Gone? The Decline in High-Growth Firms in the United States, NBER Working Paper No. 21776, s. 24 . 
po kryzysie odpowiada za obniżenie TFP o 0,2 punktu procentowego ${ }^{13}$. W literaturze zwraca się także uwagę na negatywny efekt mnożnikowy ${ }^{14}$ : kryzys osłabił zagregowany popyt, w tym inwestycje firm, co obniżyło TFP. Niższe TFP z kolei przyczynia się do spowolnienia wzrostu gospodarczego, a co za tym idzie - pesymistycznych oczekiwań i dalszego obniżenia zagregowanego popytu.

Nie bez znaczenia pozostaje także ujawnienie się słabości w bilansach dużej liczby firm (dźwignia kredytowa i rolowanie kredytów). Podczas normalnych warunków gospodarczych nie było widać zasadniczych różnic między firmami o dobrej i złej strukturze aktywów, natomiast w czasie kryzysu te drugie wyróżniają się zauważalnie niższą krańcową produktywnością ${ }^{15}$. Takie podmioty określane są niekiedy jako firmy-zombie, ponieważ mimo kryzysu gospodarczego i kłopotów z bilansem wciąż funkcjonują zamiast upaść (pozytywną cechą kryzysów ma być przecież to, że oczyszczają rynek z nieefektywnych jednostek). Ułatwia im to polityka banków, udzielających kredytów niewymagajacych spłaty kwoty podstawowej (principal) ${ }^{16}$, na które nawet te przedsiębiorstwa mogą sobie pozwolić. Taki stan rzeczy przyczynia się do obniżenia TFP przez nieefektywną alokację zasobów, zwiększanie luki technologicznej i negatywne efekty zewnętrzne. A. McGowan dowodzi, że istnienie firm-zombie obniżyło TFP o 0,6 punktu procentowego ${ }^{17}$.

Jak już zostało podkreślone, czynniki związane z kryzysem finansowym nie wydają się wystarczające do wyjaśnienia spowolnionego tempa TFP - jego spadek był obserwowalny już przed 2008 r. Można więc przypuszczać, że dużą rolę odgrywają czynniki strukturalne. Wśród nich wyróżnia się wygasajace korzyści z rewolucji ICT, akumulacji kapitału ludzkiego, liberalizacji handlu i reform strukturalnych, a także starzenie się społeczeństwa ${ }^{18}$.

\section{Kanały wpływu struktury demograficznej na TFP}

Starzenie się społeczeństwa może oddziaływać na gospodarkę w skali makro przez dwa kanały: wzrost old-age dependency ratio (ODR) oraz przez starzenie się siły roboczej ${ }^{19}$. Wzrost ODR wpłynie przede wszystkim na zwięk-

${ }^{13}$ Dzieje się tak nie tylko $\mathrm{z}$ powodu zmniejszonych efektów niższych inwestycji na $\mathrm{B}+\mathrm{R}$, lecz także $\mathrm{z}$ powodu wolniejszej dyfuzji nowych technologii związanych z kapitałem (tzw. capital-embodied).

14 G. Adler et al., op. cit., s. 7.

15 Szczególnie wysokie zróżnicowanie krańcowych produktywności występuje podczas bardzo głębokich recesji.

${ }_{16} \mathrm{~W}$ ten sposób w bilansach banków nie widać strat w przypadku braku spłaty kredytu (przynajmniej nie od razu).

17 A. McGowan, D. Andrews, The Walking Dead? Zombie Firms and Productivity Performance in OECD Countries, OECD Economics Department Working Papers No. 1372, 2017, s. 28-30.

${ }_{18}$ G. Adler et al., op. cit., s. 9 i n.

19 S. Aiyar, Ch. Ebeke, X. Shao, The Impact of Workforce Aging on European Productivity, tIMF Working Paper WP/16/238, 2016, s. 4. 
szenie obciążeń pracującego pokolenia i ciężaru długu publicznego (a zatem zwiększoną niepewność w gospodarce i słabszą zdolność do neutralizowania szoków $\left.{ }^{20}\right)$. Wzrost liczby emerytów wpływa także na zmniejszenie oszczędności w gospodarce, konieczność zwiększenia wydatków na opiekę zdrowotna oraz zmianę struktury konsumpcji ${ }^{21}$ (zwiększony popyt na usługi, szczególnie opiekę, a zmniejszony na dobra przemysłowe, przede wszystkim średniej i wysokiej techniki ${ }^{22}$ ).

Drugi kanał wpływu związany jest z zagadnieniem zmiany produktywności pracy w cyklu życia. Zgodnie $\mathrm{z}$ wynikami badań empirycznych zależność między wiekiem a produktywnością wydaje się kwadratowa. Wraz ze wzrostem przepracowanych lat można wyodrębnić efekt pozytywny (akumulacja doświadczenia ${ }^{23}$ ) oraz negatywny (deprecjacja i dezaktualizacja wiedzy ${ }^{24}$, trudniejsza adaptacja i przekwalifikowywanie się, spadek sprawności fizycznej i umysłowej). Stopień, w jakim te efekty oddziałuja, zależy także od branży gospodarki. S. Veen wyróżnia tu trzy kategorie: zawody, w których produktywność obniża się wraz z wiekiem (praca fizyczna), jest neutralna względem wieku (urzędnicy, inżynierowie) oraz wzrasta (lekarze, menedżerowie, pracownicy naukowi, prawnicy $)^{25}$. W związku z tym zagregowany wpływ na gospodarkę zależeć będzie od struktury zatrudnienia. W Europie, najbardziej dotkniętej zmianą struktury demograficznej, ok. 50\% to zawody należące do pierwszej grupy, $30 \%$ - do drugiej i $20 \%$ - do trzeciej ${ }^{26}$, w związku z czym zasadne będzie przypuszczenie o negatywnym zagregowanym wpływie.

Należy podkreślić, że powyższe badanie brało pod uwagę zatrudnionych w wieku 15-64 lat. Gdyby poszerzyć dane o produktywność pracy starszych pracowników (co byłoby jak najbardziej celowe w kontekście skali problemu, jaki stoi przed Europa, oraz dalszego wydłużania się trwania życia), wydaje się, że wyniki mogłyby być nieco inne. Intuicja podpowiada, że zależność między wiekiem a produktywnością jest rzeczywiście kwadratowa - ciężko oczekiwać, że późna starość pozostanie bez żadnego ujemnego wpływu na produktywność pracy, chociażby przez nierozłącznie z nią związane problemy ze zdrowiem. Branża gospodarki może jednak różnicować ów moment zwrotny ${ }^{27}$.

\footnotetext{
${ }^{20}$ N. Jaimovich. H. Siu, The young, the old, and the restless: demographics and business cycle volatility, „American Economic Review” 99(3), 2009, s. 804-826.

${ }^{21}$ B. Siliverstovs, K. Kholodilin, U. Thiessen, Does aging influence structural change? Evidence form panel data, „Economic System” 35(2), 2011, s. 244-260.

${ }^{22}$ Czynnik popytowy jest również możliwym kanałem wpływu starzenia się społeczeństwa na postęp techniczny.

${ }^{23} \mathrm{R}$. Disney, Can we afford to grow older? A perspective on the economics of aging, Cambridge 1996, s. $153-227$.

${ }^{24}$ S. Dixon, Implications of population ageing for the labour market, „Labour Market Trends” 111(2), 2003, s. 67-76.

${ }_{25}$ S. Veen, Demographischer Wandel, alternde Belegschaften und Betriebsproduktivitat, München 2006, s. 146-155.

${ }^{26}$ Ibidem; S. Aiyar, op. cit., s. 6-7.

${ }_{27}$ A. Borsch-Supan, M. Weiss, Productivity and age: evidence from work teams at the assembly line, „The Journal of the Economics of Ageing” 7, 2016, s. 30-42.
} 
Niezależnie od powyższego warto przyjrzeć się także badaniom dotyczącym branż generujacych innowacje. Wskazuje się, że starzejąca się siła robocza powoduje spadek wzrostu liczby zgłoszeń patentowych ${ }^{28}$. Przeciętny wiek innowatorów w USA wynosi około 48 lat, a menedżerów podejmujących innowacyjne rozwiązania - 4029. Wiek, w którym produktywność zaczyna się obniżać w tych sektorach, wydaje się zatem stosunkowo niski ${ }^{30}$. Wpływ starzenia się społeczeństwa na branże związane z innowacjami jest zatem silniejszy niż na pozostałe, co dodatkowo pogłębia spadek TFP.

\section{Agregaty makroekonomiczne a cykle koniunkturalne}

Jakie skutki dla kształtowania się cykli koniunkturalnych może mieć związek dwóch determinant tempa wzrostu PKB? W odpowiedzi na to pytanie może być pomocne prześledzenie danych dotyczacych kształtowania się agregatów makroekonomicznych (kapitału oraz stóp wzrostu postępu technicznego i podaży pracy) w czasie. Zostały one zaprezentowane oddzielnie dla Europy i USA na wykresach oraz w tabelach.

\section{Wykres 2}

Tempo wzrostu PKB, postępu technicznego, przyrostu demograficznego i kapitału w USA w latach 1880-2010 (dziesięcioletnie stopy wzrostu)

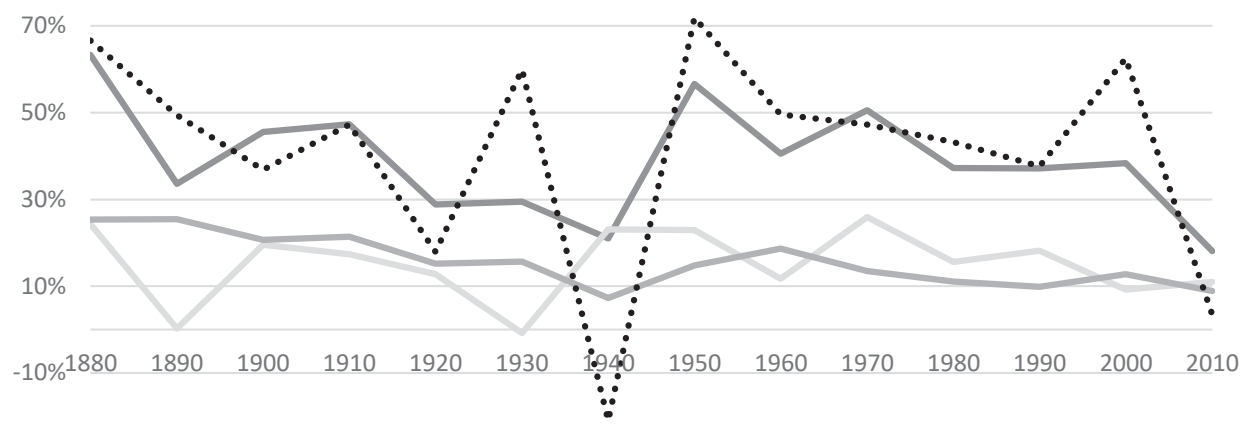

$-30 \%$

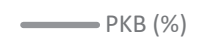
Postęp techniczny (\%) Przyrost demograficzny (\%) Kapitał \%

Źródło: opracowanie własne na podstawie Maddison Historical Statistics, <http://www.ggdc.net/maddison/oriindex.htm> [dostęp: 14.02.2018]; Piketty's Capital in the 21st century Database, <http://piketty. pse.ens.fr/en/capital21c2> [dostęp: 14.02.2018].

${ }_{28}$ Y. Aksoy, T. Grasl, R. Smith, Demographic Structure and Macroeconomic Trends, CESifo Working Paper Series No. 5872, s. 20 i n.

${ }^{29}$ J. Feyrer, Aggregate evidence on the link between age structure and productivity, „Population and Development Review" 44, 2008, s. 78-99.

30 Dla porównania, produktywność pracowników w niemieckich fabrykach samochodów obniża się dopiero po 60 roku życia (A. Borsch-Supan, M. Weiss, op. cit.). 


\section{Tabela 1}

Cykle koniunkturalne w USA a kształtowanie się zmiennych makroekonomicznych w latach 1880-2010 (dziesięcioletnie stopy wzrostu)

a) Ożywienia

\begin{tabular}{|c|c|c|c|}
\hline Rok & Kapital & TFP & Przyrost demograficzny \\
\hline 1910 & wzrost & spadek & niewielki wzrost \\
\hline 1950 & wzrost & bez zmian & wzrost \\
\hline 1970 & wzrost & wzrost & niewielki spadek \\
\hline
\end{tabular}

b) Spowolnienia

\begin{tabular}{|c|c|c|c|}
\hline Rok & Kapital & TFP & Przyrost demograficzny \\
\hline 1890 & spadek & spadek & bez zmian \\
\hline 1920 & spadek & spadek & spadek \\
\hline 1940 & spadek & wzrost & spadek \\
\hline 1960 & spadek & spadek & wzrost \\
\hline
\end{tabular}

Źródło: opracowanie własne na podstawie Maddison Historical Statistics, <http://www.ggdc.net/maddison/oriindex.htm> [dostęp: 14.02.2018]; Piketty's Capital in the 21st century Database, <http://piketty. pse.ens.fr/en/capital21c2> [dostęp: 14.02.2018].

\section{Wykres 3}

Tempo wzrostu PKB, postępu technicznego, przyrostu demograficznego i kapitału w Europie w latach 1880-2010 (dziesięcioletnie stopy wzrostu)

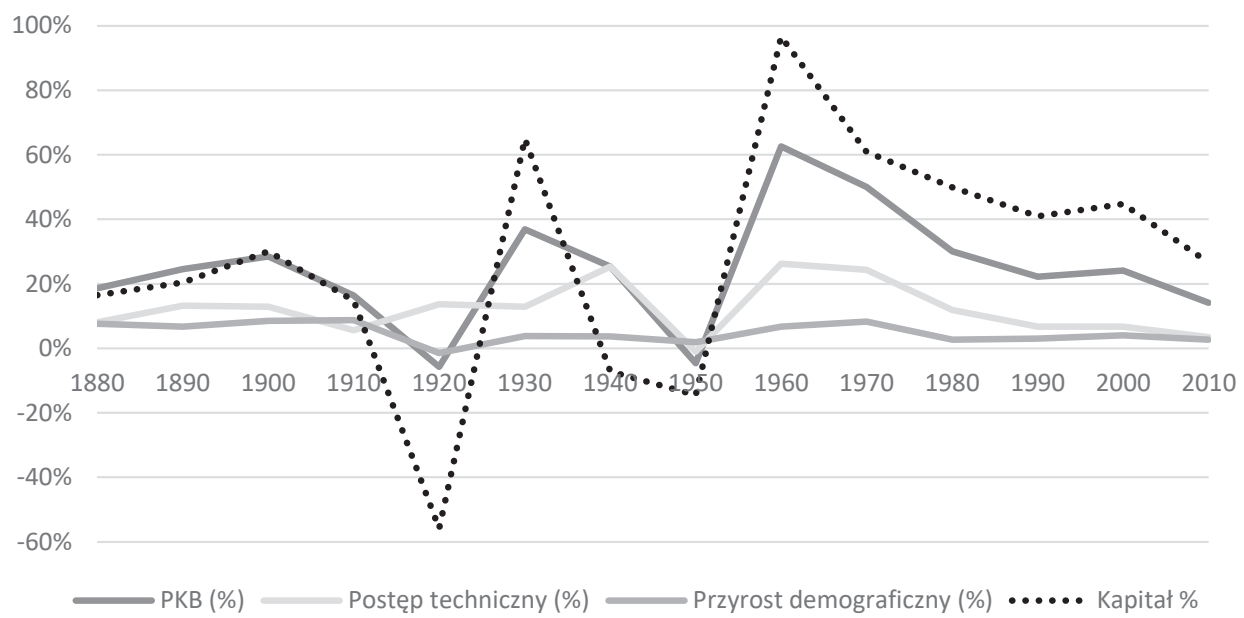

Źródło: opracowanie własne na podstawie Maddison Historical Statistics, <http://www.ggdc.net/maddison/oriindex.htm> [dostęp: 14.02.2018]; Piketty's Capital in the 21st century Database, <http://piketty. pse.ens.fr/en/capital21c2> [dostęp: 14.02.2018]. 


\section{Tabela 2}

Cykle koniunkturalne w Europie a kształtowanie się zmiennych makroekonomicznych w latach 1880-2010 (dziesięcioletnie stopy wzrostu)

a) Ożywienia

\begin{tabular}{|c|c|c|c|}
\hline Rok & Kapital & TFP & Przyrost demograficzny \\
\hline 1900 & wzrost & wzrost & nieznaczny wzrost \\
\hline 1930 & wzrost & bez zmian & wzrost \\
\hline 1960 & wzrost & wzrost & wzrost \\
\hline
\end{tabular}

b) Spowolnienia

\begin{tabular}{|c|c|c|c|}
\hline Rok & Kapital & TFP & Przyrost demograficzny \\
\hline 1920 & spadek & wzrost & spadek \\
\hline 1950 & spadek & spadek & spadek \\
\hline
\end{tabular}

Źródło: opracowanie własne na podstawie Maddison Historical Statistics, <http://www.ggdc.net/maddison/oriindex.htm> [dostęp: 14.02.2018]; Piketty's Capital in the 21st century Database, <http://piketty. pse.ens.fr/en/capital21c2> [dostęp: 14.02.2018].

Powyższe dane pozwalają stwierdzić, że w warunkiem zaistnienia ożywienia $\mathrm{w}$ gospodarce jest wzrost przynajmniej dwóch z trzech zmiennych, natomiast spadek co najmniej dwóch oznacza spowolnienie. Jak już podkreślono, tempo przyrostu siły roboczej w Europie nie wzrośnie w najbliższej przyszłości, wobec czego potencjalnymi źródłami ożywienia pozostaja postęp techniczny i kapitał. Jeśli jednak uwzględnimy negatywny związek między starzejącym się społeczeństwem a postępem technicznym, efektem będzie gospodarka recesyjna. Co więcej, wydaje się, że brak również perspektyw na wzrost tempa przyrostu kapitału, głównie z powodu skutków kryzysu finansowego, w tym bardziej restrykcyjnych warunków kredytowych, utraty zaufania na rynkach finansowych, zwiększonej niepewności ekonomiczno-politycznej i słabości zagregowanego popytu.

\section{Rewizja prognoz}

Zgodnie z wynikami badań empirycznych starzenie się siły roboczej odpowiadało dotychczas za coroczny spadek TFP w Europie o wartość wahająca się od 0,1 (Aiyar $^{31}$ ) do 0,5 (Adler ${ }^{32}$ ) punktu procentowego ${ }^{33}$. Aiyar przewiduje, że do 2035 TFP będzie zmniejszał się corocznie o 0,2 punktu procentowego (w niektórych krajach nawet o $0,6^{34}$ ), co wydaje się znacznym wynikiem, mając

31 S. Aiyar, op. cit., s. 7-15.

32 G. Adler, op. cit., s. 21.

${ }^{33}$ W przypadku pierwszego badania odnośny szereg czasowy to 1984-2007, drugiego: 19852014, przy czym pierwsze badanie dotyczyło tylko Europy. Niezależnie od powyższego dziwi dość duża różnica w oszacowaniach.

${ }^{34}$ Mowa o krajach najbardziej dotkniętych problemem i jednocześnie wysoce zadłużonych: Hiszpania, Portugalia, Włochy, Słowenia, Słowacja i Irlandia. 
na uwadze, że prognoza tego wskaźnika wynosi tylko 1\% rocznie. Natomiast zgodnie z wynikami badań Adlera należałoby oczekiwać spadku TFP o więcej niż 0,5 punktu procentowego, czyli o ponad połowę.

Celem oszacowania przyszłych stóp wzrostu PKB w Europie dotkniętej problemem zmiany struktury demograficznej można posłużyć się dekompozycją Solowa, w którym to ujęciu tempo to jest sumą tempa postępu technicznego, tempa wzrostu kapitału przeważonego udziałem jego wynagrodzenia w PKB oraz tempa wzrostu siły roboczej przeważonej odnośnym udziałem $\mathrm{w} \mathrm{PKB}^{35}$. Zgodnie z teorią zrównoważonego wzrostu gospodarczego za udziały wynagrodzenia czynników produkcji w PKB przyjęto odpowiednio 33\% oraz $67 \%^{36}$.

W optymistycznym scenariuszu stopa wzrostu postępu technicznego będzie wynosiła 1\%, kapitał będzie kształtował się jak w latach 1990-2000 $(3,4 \%)$, a tempo wzrostu siły roboczej będzie opiewało na 0,1\% (prognoza wzrostu demograficznego przez World Bank dla lat 2017-2024). Takie parametry determinują stopę wzrostu PKB w wysokości 2,19\%. Przyjmując jednak gorszy scenariusz, w którym stopa wzrostu postępu technicznego obniży się o połowę, kapitał będzie rósł w tempie 2,4\% jak w latach 2000-2010, a tempo wzrostu siły roboczej będzie wynosiło - $0,2 \%$ (prognoza wzrostu demograficznego dla lat 2046-2050), otrzymujemy stopę wzrostu PKB w wysokości $1,16 \%$.

Podsumowując, prognozy wskaźników gospodarczych oparte na istnieniu związku między strukturą demograficzną a postępem technicznym są bardzo niskie. Przy tym oszacowania te są raczej górnymi granicami stóp wzrostu, gdyż jak wskazano w pkt II.5 należy się liczyć z często występującymi recesjami. Warto w tym miejscu przypomnieć, że zmiana struktury demograficznej spowoduje także osłabienie możliwości neutralizacji szoków.

\section{WYKORZYSTANIE MODELU OLG}

\section{Model OLG z endogenicznym wzrostem}

Do celów analizy zastosowano model nakładających się pokoleń (overlapping generations - OLG). W gospodarce występują w każdym okresie trzy pokolenia: młodych, w średnim wieku oraz emerytów. Dwie pierwsze kategorie składają się na siłę roboczą w gospodarce; natomiast ostatnia grupa nie pracuje - utrzymuje się z tego, co zaoszczędziła wcześniej. $N_{t}$ oznacza kohortę uro-

35 Wzór ten otrzymuje się przez zlogarytmowanie i zróżniczkowanie po czasie funkcji produkcji Cobba-Douglasa. Por. M. Burda, Ch. Wyplosz, op. cit., s. 128-130; D. Romer, op. cit., s. 44-45.

36 Tezę o stabilnym udziale wynagrodzenia czynników produkcji w PKB wysnuł Kaldor podczas analizy danych empirycznych. Obserwacja ta należy do zbioru tzw. faktów Kaldora i stała się podstawą teorii ścieżki zrównoważonego wzrostu w modelach z zakresu teorii wzrostu; D. Acemoglu, Introduction to Modern Economic Growth, New Jersey 2009, s. 57. 
dzonych w okresie $t$. Stopą przyrostu naturalnego jest $n_{t}$. Ze względu na fakt występowania w modelu tylko trzech pokoleń, jeden okres w tej gospodarce wynosi ok. 20 lat.

$$
N_{t}=\left(1+n_{t}\right) N_{t-1}
$$

Aby wprowadzić do gospodarki wzrost inny niż oparty na przyroście siły roboczej, a co za tym idzie - bardziej zbliżyć się do rzeczywistości, zdefiniujmy przez $A_{t}$ poziom dostępnej w gospodarce technologii, który rośnie w tempie $\mu_{t}$. Na tempo wzrostu technologii składają się dwa komponenty: produktywność wykonywanej pracy $\mathrm{w}$ sektorze $\mathrm{B}+\mathrm{R} z_{t}$ oraz odsetek pracujacych tamże osób (w relacji do zatrudnienia ogółem) $u_{t}$. Taka specyfikacja pozwoli nam na wyekstrahowanie wpływu struktury demograficznej na postęp techniczny. Zgodnie z wynikami badań przytoczonymi w pkt I (a także intuicja), w „srebrnej gospodarce" maleje udział innowatorów.

$$
\begin{gathered}
A_{t}=\left(1+\mu_{t}\right) A_{t-1} \\
\mu_{t}=\left(1+z_{t}\right)\left(1+u_{t}\right)-1
\end{gathered}
$$

Gospodarstwa domowe maksymalizują użyteczność przez funkcję celu, uwzględniająca zarówno teraźniejsza, jak i przyszłą konsumpcję (ta druga przeważona jest współczynnikiem dyskontującym, czyli miarą niecierpliwości agentów). Czynią to, mając na względzie ograniczenie budżetowe w trzech okresach: płacę mogą rozdzielić na konsumpcję i oszczędności, z których to finansują sobie okres braku aktywności zawodowej.

$$
\begin{gathered}
U_{t}=u\left(c_{1, t}\right)+\beta u\left(c_{2, t+1}\right)+\beta^{2} u\left(c_{3, t+2}\right) \\
w_{t}=s_{1, t+1}+p_{t} c_{1, t} \\
R_{t+1} s_{1, t+1}+w_{t+1}=s_{2, t+2}+p_{t+1} c_{2, t+1} \\
p e n_{t+2}+R_{t+2} s_{2, t+2}=p_{t+2} c_{3, t+2} \\
L_{t}= \\
u\left(c_{1, t}\right)+\beta u\left(c_{2, t+1}\right)+\beta^{2} u\left(c_{3, t+2}\right)+\lambda_{1}\left(s_{1, t+1}+p_{t} c_{1, t}-w_{t}\right)+ \\
+\lambda_{2}\left(s_{2, t+2}+p_{t+1} c_{2, t+1}-w_{t+1}-R_{t+1} s_{1, t+1}\right)+\lambda_{3}\left(p_{t+2} c_{3, t+2}-p e n_{t+2}-R_{t+2} s_{2, t+2}\right)
\end{gathered}
$$

Licząc pochodna po każdej zmiennej decyzyjnej, uzyskujemy równanie Eulera, łączące dzisiejszą konsumpcję z konsumpcją przyszłą. Sprowadza się ono do „wyrównywania” krańcowej korzyści z konsumpcji dzisiejszej i jutrzejszej, przy czym ta druga przeważona jest współczynnikiem dyskontującym. Przy konkretnej postaci funkcyjnej problem wyliczenia optymalnych wartości konsumpcji sprowadzi się do dokonania odpowiedniego podstawienia. 


$$
\begin{gathered}
c_{1}: u^{\prime}\left(c_{1, t}\right)=\lambda_{1} p_{t} \\
c_{2}: \beta u^{\prime}\left(c_{2, t+1}\right)=\lambda_{2} p_{t+1} \\
c_{2}: \beta^{2} u^{\prime}\left(c_{3, t+2}\right)=\lambda_{3} p_{t+2} \\
s_{1}: \lambda_{1}=\lambda_{2} R_{t+1} \\
s_{2}: \lambda_{2}=\lambda_{3} R_{t+2} \\
u^{\prime}\left(c_{1, t}\right)=\lambda_{2} R_{t+1} p_{t} \\
u^{\prime}\left(c_{1, t}\right)=\frac{\beta u^{\prime}\left(c_{2, t+1}\right)}{p_{t+1}} R_{t+1} p_{t} \\
p_{t+1} u^{\prime}\left(c_{1, t}\right)=\beta u^{\prime}\left(c_{2, t+1}\right) R_{t+1} p_{t} \\
\beta u^{\prime}\left(c_{2, t+1}\right)=\lambda_{3} R_{t+2} p_{t+1} \\
u^{\prime}\left(c_{2, t+1}\right)=\frac{\beta u^{\prime}\left(c_{3, t+2}\right)}{p_{t+2}} R_{t+2} p_{t+1} \\
p_{t+2} u^{\prime}\left(c_{2, t+1}\right)=\beta R_{t+2} p_{t+1} u^{\prime}\left(c_{3, t+2}\right)
\end{gathered}
$$

Wszystkie zagregowane zmienne zostały znormalizowane do rozmiaru nowo narodzonego pokolenia. Ze względu na to, że praca wspierana jest postępem technicznym, należy dokonać przeliczenia na jednostkę efektywnej pracy (tzw. stacjonaryzacja). Wiąże się to z faktem, że pożądane jest, aby w stanie ustalonym zmienne na jednostkę nie zmieniały się w czasie. W gospodarce z nieustannym postępem technicznym nie będzie to możliwe (będzie ona cały czas rosła), dlatego należy rozpatrywać pracę w kategoriach efektywnej (wspomaganej postępem technicznym) - taka zmienna nie będzie podlegała zmianom w steady state.

Każde gospodarstwo domowe dostarcza w sposób nieelastyczny jednostkę pracy $L_{t}$. Niech $S_{t}$ i $C_{t}$ oznaczają odpowiednio zagregowane oszczędności i konsumpcję, podczas gdy $s_{t}$ oraz $c_{t}$ - oszczędności oraz konsumpcję na jednostkę efektywnej pracy.

$$
\begin{gathered}
L_{t}=\frac{A_{t} N_{t}+A_{t-1} N_{t-1}}{A_{t} N_{t}}=\frac{\left(1+n_{t}\right)\left(1+\mu_{t}\right) N_{t-1}+N_{t-1}}{\left(1+n_{t}\right)\left(1+\mu_{t}\right) N_{t-1}}=1+\frac{1}{\left(1+n_{t}\right)\left(1+\mu_{t}\right)} \\
S_{t}=\frac{A_{t-1} N_{t-1} S_{1, t}+A_{t-2} N_{t-2} S_{2, t}}{A_{t} N_{t}}= \\
=\frac{s_{1, t}}{\left(1+n_{t}\right)\left(1+\mu_{t}\right)}+\frac{S_{2, t}}{\left(1+n_{t}\right)\left(1+n_{t-1}\right)\left(1+\mu_{t}\right)\left(1+\mu_{t-1}\right)} \\
=c_{1, t}+\frac{A_{t} N_{t} C_{1, t}+A_{t-1} N_{t-1} C_{2, t}+A_{t-2} N_{t-2} C_{3, t}}{\left(1+n_{t}\right)\left(1+\mu_{t}\right)}=\frac{A_{t} N_{t}}{\left(1+n_{t}\right)\left(1+n_{t-1}\right)\left(1+\mu_{t}\right)\left(1+\mu_{t-1}\right)}
\end{gathered}
$$


Po sprowadzeniu funkcji produkcji $Y_{t}$ do postaci intensywnej $y_{t}$ (produkcja na jednostkę efektywnej pracy), co jest możliwe dzięki własności jednorodności, można wyliczyć ceny czynników produkcji (stopa procentowa) oraz (płaca).

$$
\begin{gathered}
Y_{t}=F\left(A_{t}, L_{t}, K_{t}\right) \\
y_{t}=\frac{Y_{t} A_{t}}{L_{t} A_{t}}=f\left(k_{t}\right) \\
r_{t}=f^{\prime}\left(k_{t}\right)-\delta \\
w_{t}=f\left(k_{t}\right)-f^{\prime}\left(k_{t}\right) k_{t} \\
Y_{t}=w_{t} L_{t}+\left(r_{t}+\delta\right) K_{t}
\end{gathered}
$$

Celem zapewnienia równowagi w gospodarce należy dodać jeszcze równania równoważące popyt i podaż na rynku kapitałowym oraz dóbr.

$$
\begin{gathered}
K_{t}=S_{t} \\
Y_{t}=C_{t}+\left(1+n_{t+1}\right) K_{t+1}-(1-\delta) K_{t} \\
I_{t}=\left(1+n_{t+1}\right) K_{t+1}-(1-\delta) K_{t}
\end{gathered}
$$

Aby wyliczyć długookresową równowagę gospodarki, należy założyć określona postać funkcji użyteczności oraz produkcji. W omawianym przykładzie przyjęto funkcję stałej relatywnej awersji do ryzyka jako tę pierwsza, natomiast jako druga - neoklasyczną funkcję produkcji. Dzięki temu możliwe będzie określenie wielkości konsumpcji poszczególnych kohort, a także cen czynników produkcji.

$$
\begin{gathered}
u(c)=\frac{c^{1-1 / \gamma}}{1-1 / \gamma} \\
u^{\prime}(c)=c^{-1 / \gamma} \\
c_{2}=(\beta R)^{\gamma} c_{1} \\
c_{3}=(\beta R)^{\gamma} c_{2}=(\beta R)^{2 \gamma} c_{1} \\
p c_{1}+\frac{p c_{2}}{R}+\frac{p c_{3}}{R^{2}}=w_{1}+\frac{w_{2}}{R}+\frac{p e n}{R^{2}}=L T I_{1} \\
p c_{1}+\frac{p(\beta R)^{\gamma} c_{1}}{R}+\frac{p(\beta R)^{2 \gamma} c_{1}}{R^{2}}=L T I_{1} \\
c_{1}\left[p\left(1+\beta^{\gamma} R^{\gamma-1}+\beta^{2 \gamma} R^{2 \gamma-2}\right)\right]=L T I_{1} \\
c_{1}=\frac{1}{p}\left[1+\beta^{\gamma} R^{\gamma-1}+\beta^{2 \gamma} R^{2 \gamma-2}\right]^{-1} L T I_{1} \\
f(k)=k^{\alpha} \\
f^{\prime}(k)=\alpha k^{\alpha-1} \\
r=\alpha k^{\alpha-1}-\delta \\
w=(1-\alpha) k^{\alpha}
\end{gathered}
$$




\section{Symulacja}

Aby zbadać implikacje związku dwóch omawianych komponentów dla wyników gospodarczych, dokonano czterech różnych symulacji dla 30 okresów - każda dla innej wartości tempa przyrostu naturalnego oraz postępu technicznego, co podsumowano w tabeli 3. Pierwszy scenariusz jest wariantem optymistycznym, w którym nie tylko nie nastapi spadek tempa przyrostu naturalnego, ale nieco się zwiększy (z górnej prognozy 0,1\% do 0,2\%). Tempo postępu technicznego również zostało przyjęte w górnej granicy możliwej do osiagnięcia przez państwa rozwinięte. W drugim scenariuszu ta stopa wzrostu pozostaje bez zmian, natomiast przyrost naturalny obniża się do zera. To wariant, w którym starzenie się społeczeństwa nie wpływa na tempo wzrostu innowacyjności. Założenie to jest uchylane w trzeciej symulacji - obniża się ono do swojej dolnej granicy prognozy (warto przypomnieć, że przewidywana stopa wzrostu dla państw rozwiniętych na najbliższe lata wynosi tylko 1\%, podczas gdy starzenie się społeczeństwa zgodnie z wynikami badań empirycznych może tę wartość obniżać aż o 0,8 punktu procentowego). W czwartym scenariuszu przyrost naturalny osiaga wartości ujemne (co również znajduje odzwierciedlenie w najgorszych prognozach Eurostatu).

Tabela 3

Wartości tempa przyrostu naturalnego oraz postępu technicznego przyjęte w różnych scenariuszach symulacji

\begin{tabular}{|c|c|c|c|c|}
\hline Scenariusz & $\mathbf{1}$ & $\mathbf{2}$ & $\mathbf{3}$ & $\mathbf{4}$ \\
\hline $\mathrm{N}$ & $0,2 \%$ & $0 \%$ & $0,0 \%$ & $-0,2 \%$ \\
\hline$\mu$ & $2,0 \%$ & $2 \%$ & $0,2 \%$ & $0,2 \%$ \\
\hline
\end{tabular}

Źródło: opracowanie własne.

Przy obecnej specyfikacji modelu, tj. uwzględnieniu związku między tempem przyrostu naturalnego a postępu technicznego, właściwe byłoby dokonanie jedynie symulacji pierwszej, trzeciej i czwartej. Druga została jednak wprowadzona dla celów porównawczych. Pozwoli to odpowiedzieć na pytanie, jak rozpatrywany związek zmienia wyniki gospodarcze.

$\mathrm{W}$ symulacjach przyjęto parametryzację określoną w tabeli 4. Wartości współczynnika dyskontującego, udziału kapitału w wynagrodzeniu oraz stopy deprecjacji zostały dobrane tak, by odpowiadały teorii i innym badaniom. Współczynnik relatywnej awersji do ryzyka $\gamma$ został ustalony na poziomie $1-\mathrm{w}$ obliczu takiego założenia funkcja CRRA będzie miała postać funkcji logarytmicznej $u(c)=\ln (c)$. 
Tabela 4

Parametryzacja modeli

\begin{tabular}{|c|c|}
\hline Parametr & Przyjęta wartość \\
\hline$\beta$ & 0,97 \\
\hline$\alpha$ & 0,33 \\
\hline$\gamma$ & 1,00 \\
\hline$\delta$ & 0,10 \\
\hline
\end{tabular}

Źródło: opracowanie własne na podstawie parametryzacji przyjętej w literaturze (wynikającej z badań empirycznych).

Porównanie zostanie dokonane na podstawie wartości przyjmowanych przez agregaty ekonomiczne w stanie ustalonym. Pamiętając jednak o tym, że sa one przeliczane na jednostkę efektywnej pracy, trzeba dokonać odpowiednich operacji algebraicznych. W tym celu należy przyjąć założenie co do liczebności pokolenia narodzonego w okresie $t=0$ (przyjęto $N_{t=0}=100$ ). Dzięki temu możliwe będzie obliczenie nie tylko liczebności każdego następnego pokolenia, lecz także efektywnej pracy (mając na względzie, że rośnie ona w tempie $\mu$, co pozwoli na zamianę wartości per effective labor unit na agregaty.

Tabela 5

Wartości agregatów ekonomicznych w czterech scenariuszach symulacji (po upływie 30 okresów)

\begin{tabular}{|c|c|c|c|c|}
\hline Zmienna & $\begin{array}{c}\boldsymbol{n}=\mathbf{0 , 2} \% \\
\boldsymbol{\mu}=\mathbf{2 \%}\end{array}$ & $\begin{array}{c}\boldsymbol{n}=\mathbf{0} \% \\
\boldsymbol{\mu}=\mathbf{2} \%\end{array}$ & $\begin{array}{c}\boldsymbol{n}=\mathbf{0} \% \\
\boldsymbol{\mu}=\mathbf{0 , 2} \%\end{array}$ & $\begin{array}{c}\boldsymbol{n}=\mathbf{- 0 , 0 2} \% \\
\boldsymbol{\mu}=\mathbf{0 , 2} \%\end{array}$ \\
\hline$Y$ & 58,95 & 60,64 & 46,63 & 47,00 \\
\hline$C$ & 47,47 & 47,96 & 37,43 & 22,95 \\
\hline$C 1$ & 2,82 & 29,00 & 22,30 & 14,65 \\
\hline$K 2$ & 20,46 & 19,81 & 15,13 & 9,61 \\
\hline
\end{tabular}

$Y$ - produkcja, $C$ - konsumpcja ogółem, $C 1$ - konsumpcja pracujących, $C 2$ - konsumpcja emerytów, $K$ - kapitał

Źródło: opracowanie własne na podstawie symulacji modelu. 
Tabela 6

Wartości agregatów ekonomicznych przeliczone per capita w czterech scenariuszach symulacji (po upływie 30 okresów)

\begin{tabular}{|c|c|c|c|c|}
\hline Zmienna & $\begin{array}{c}n=0,2 \% \\
g=2 \%\end{array}$ & $\begin{array}{l}n=0 \% \\
g=2 \%\end{array}$ & $\begin{array}{c}n=0 \% \\
g=0,2 \%\end{array}$ & $\begin{array}{c}n=-0,02 \% \\
g=0,2 \%\end{array}$ \\
\hline$y$ & 0,56 & 0,61 & 0,47 & 0,51 \\
\hline$c$ & 0,45 & 0,48 & 0,35 & 0,41 \\
\hline$c 1$ & 0,03 & 0,29 & 0,22 & 0,24 \\
\hline$c 2$ & 0,19 & 0,20 & 0,14 & 0,16 \\
\hline$k$ & 0,11 & 0,12 & 0,09 & 0,10 \\
\hline
\end{tabular}

$y$ - produkcja per capita, $c$ - konsumpcja ogółem per capita, c1- konsumpcja pracujacych per capita, $c 2$ - konsumpcja emerytów per capita, $k$ - kapitał per capita

Źródło: opracowanie własne na podstawie symulacji modelu.

Na podstawie uzyskanych danych można stwierdzić, że samo zmniejszenie tempa przyrostu naturalnego nie wydaje się istotnym problemem dla rozpatrywanej gospodarki. Wręcz przeciwnie - obserwowalny jest wzrost zagregowanego produktu oraz produktu per capita. Spowodowane jest to faktem, że podobny postęp techniczny skutkuje podobnym przyrostem efektywnej pracy (nawet jeśli różni się stopa przyrostu naturalnego, różnica ta jest relatywnie niewielka), natomiast liczba ludności, na którą dzielone są owoce tej pracy, spada. Dzieje się tak prawdopodobnie także dlatego, że model nie uwzględnia sektora państwowego i konieczności sfinansowania emerytur dla starszego pokolenia.

Można jednak zaobserwować, że spowolnienie tempa postępu technicznego widocznie zmniejsza produkt oraz konsumpcję. Skłania to do tezy, że potencjalny związek między tymi dwiema zmiennymi jest dla gospodarki dużo bardziej dotkliwy niż sam fakt wyhamowywania przyrostu naturalnego. Tym samym to połączenie stwarza zagrożenie dla przyszłych wyników ekonomicznych, a także poziomu życia i stabilności społecznej. Wydaje się, że zamortyzowanie negatywnego wpływu struktury demograficznej na postęp techniczny powinno być jednym z głównych zadań polityki gospodarczej w przyszłości.

\section{ZAKOŃCZENIE}

Celem artykułu była analiza problematyki związku zmiany struktury demograficznej z tempem postępu technicznego. Motywację stanowiły prognozy znikomego przyrostu naturalnego w Europie oraz najnowsze badania doty- 
czące wpływu wieku na produktywność pracy, według których starzenie się społeczeństwa obniży TFP w Europie nawet o ponad połowę.

Na podstawie analizy szeregów czasowych tempa zmian zmiennych ekonomicznych (kapitał, TFP, przyrost naturalny) w cyklach koniunkturalnych można wysnuć wniosek, że zmiana struktury demograficznej może mieć niekorzystny wpływ nie tylko na długookresowy trend, co już było wskazywane w literaturze, ale także na przebieg cyklu koniunkturalnego. Ożywienia gospodarcze następuja, gdy co najmniej dwie z badanych zmiennych rosna, spowolnienia - gdy przynajmniej dwie spadaja. Negatywny związek między dwoma komponentami oznaczałby brak szans na korzystną koniunkturę w przyszłości.

Korzystając ze wzoru na dekompozycję Solowa, dokonano uwzględniającej omawianą zależność rewizji prognoz stóp wzrostu PKB w Europie - odpowiednio $2,19 \%$ (scenariusz optymistyczny) oraz $1,16 \%$ (pesymistyczny). Biorac pod uwagę konkluzje dotyczące przyszłego kształtowania się cykli koniunkturalnych, należy traktować powyższe wartości raczej jako górną granicę. Można zauważyć, że wpływ starzejącego się społeczeństwa na tempo postępu technicznego znacznie obniżyłby stopę wzrostu PKB w przyszłości.

Także porównanie wyników symulacji modelu OLG zmodyfikowanego w taki sposób, by uwzględniał zależność zmian demograficznych i postępu technicznego, pozwala stwierdzić, że omawiany związek widocznie pogłębia problemy wynikające ze starzenia się społeczeństwa i znacznie pogarsza wyniki gospodarcze.

mgr Agata Skorupka

Szkoła Gtówna Handlowa w Warszawie

as58771@doktorant.sgh.waw.pl

\section{THE IMPACT OF THE AGEING POPULATION ON TECHNICAL PROGRESS}

\section{Summary}

The article analyses the relation between the ageing of society and technical progress, which seems to be a particularly important subject in the view of the inevitability of changes in the demographic structure and the latest analyses of the impact of this phenomenon on labour productivity. On the basis of the results of empirical studies, forecasts of the GDP growth rate for Europe have been revised, taking into account this correlation. It appears that the existence of dependencies lowers this indicator significantly. Moreover, the analysis of the time series of macroeconomic aggregates has shown that a change in the demographic structure may have a severe impact not only on the long-term trend but also on the course of economic cycles. Furthermore, the article extends the classic model of overlapping generations in such a way as to reflect the impact of population ageing on technical progress. It has been shown that the impact of the modification is far greater than the impact of merely taking into account the slowdown resulting from demographic trends. 
